\title{
Combination therapy for erectile dysfunction: an update review
}

\author{
Rohit R Dhir ${ }^{1}$, Hao-Cheng Lin $^{1,2}$, Steven E Canfield ${ }^{1,3}$ and Run Wang ${ }^{1,3}$
}

The introduction of oral phosphodiesterase-5 inhibitors (PDE5Is) in the late 1990s and early 2000s revolutionized the field of sexual medicine and PDE5Is are currently first-line monotherapy for erectile dysfunction (ED). However, a significant proportion of patients with complex ED will be therapeutic non-responders to PDE5I monotherapy. Combination therapy has recently been adopted for more refractory cases of ED, but a critical evaluation of current combination therapies is lacking. A thorough PubMed and Cochrane Library search was conducted focusing on the effectiveness of combination therapies for ED in therapeutic non-responders to PDE5I therapy. Journal articles spanning the time period between January 1990 and December 2010 were reviewed. Criteria included all pertinent review articles, randomized controlled trials, cohort studies and retrospective analyses. References from retrieved articles were also manually scanned for additional relevant publications. Published combination therapies include PDE5I plus vacuum erectile device (VED), intraurethral medication, intracavernosal injection ( $\mathrm{Cl}$ ), androgen supplement, $\alpha$-blocker or miscellaneous combinations.

Based on this review, some of these combination treatments appeared to be quite effective in preliminary testing. Caution must be advised, however, as the majority of combination therapy articles in the last decade have numerous limitations including study biases and small subject size. Regardless of limitations, present combination therapy research provides a solid foundation for future studies in complex ED management.

Asian Journal of Andrology (2011) 13, 382-390; doi:10.1038/aja.2011.2; published online 21 March 2011

Keywords: combination therapy; intracavernosal injection; erectile dysfunction; phosphodiesterase-5 inhibitors; vacuum erectile device

\section{INTRODUCTION}

Erectile dysfunction (ED), a sexual disorder consisting of penile rigidity insufficient for satisfactory sexual intercourse, currently affects $52 \%$ of 40 - to 70 -year-old men. ${ }^{1}$ Current projections indicate an increase in the prevalence of ED due to aging as well as the continued abundance of comorbidities such as coronary artery disease, hypertension and diabetes in industrialized nations. Over 320 million people in Westernized nations will be affected by 2025, more than double the prevalence seen 15 years ago, indicating a growing need to reevaluate ED therapeutic strategies. ${ }^{2}$ Over the past four decades, the treatment of ED has evolved rapidly and is still changing with new discovery. Before the 1970s, psychotherapy was the primary means of treatment and undoubtedly was limited in its success. During the 1970s, penile prostheses combined with psychotherapy remained popular but relatively inaccessible. The 1980 s was dominated by intracavernous injection (ICI) and followed by intraurethral therapy in the mid-1990s. Despite this transition towards non-surgical management, available treatment modalities were not patient-friendly. The introduction of oral phosphodiesterase- 5 inhibitors (PDE5Is) in the late 1990s and early 2000s revolutionized the field of sexual medicine and PDE5Is are currently first-line monotherapy. ${ }^{1}$

Unfortunately, effective treatment of complex ED still stands to be improved despite the convenience of oral therapy. Some patients continue to have medical contraindications to PDE5I therapy such as concurrent nitrate use. Others cannot tolerate its bothersome side effects including headaches, dizziness, and vision and hearing changes. Furthermore, $11 \%-44 \%$ of patients will be therapeutic non-responders to PDE5I monotherapy. ${ }^{3}$ For this patient subset, second-line treatments such as the vacuum erection device (VED), intraurethral vasoactive prostanoids and ICI can be offered. The addition of adrenoreceptor antagonists, centrally acting dopamine agonists, androgen replacement therapy, and other experimental drugs also provide physicians a vast assortment of modalities to implement before considering surgical intervention. Despite these advances, satisfactory ED treatment still continues to be a clinically challenging entity. Combination therapy has recently gained widespread acceptance for more refractory and complex cases of ED. It is important to critically evaluate the current combination therapies based on the clinic evidences before endorsement. Our review will focus on the available combination therapies for ED after PDE5I monotherapy failure.

\section{ARTICLES' SEARCH METHODS}

A thorough PubMed and Cochrane Library search was conducted on combination therapies for ED. Journal articles spanning the time period between January 1990 and December 2010 were reviewed. Inclusion criteria were articles evaluating combination therapy for men refractory to PDE5I monotherapy. The majority of combinations involved the use of PDE5I, but other combinations were also included

${ }^{1}$ Division of Urology, University of Texas Medical School at Houston, Houston, TX 77030, USA; ${ }^{2}$ Department of Urology, Affiliated Drum Tower Hospital, Nanjing University School of Medicine, Nanjing 210008, China, and ${ }^{3}$ Department of Urology, University of Texas MD Anderson Cancer Center, Houston, TX 77030, USA Correspondence: Professor R Wang (Run.Wang@uth.tmc.edu)

Received: 8 January 2011; Revised: 2 February 2011; Accepted: 18 February 2011; Published online: 21 March 2011 
in the review. Literary searches were restricted to the English language and included combinations of the following terms: erectile dysfunction, combination therapy, PDE5I, VED, ICI, intraurethral alprostadil, medicated urethral system for erections (MUSE), androgen supplementation, penile prosthesis implantation and psychosocial treatment. All pertinent review articles, randomized controlled trials, cohort studies and retrospective analyses were included. References from retrieved articles were also manually scanned for additional relevant publications.

\section{RESULTS}

The published combination therapies include PDE5I plus VED, intraurethral medication, ICI, androgen supplement, $\alpha$-blocker, other medications or miscellaneous combinations (not involving PDE5I). Due to the heterogeneous assortment of current combination therapies and significant individual study limitations, the meta-analysis of the data was not possible. The results of current combination treatment data is therefore presented as a systematic review in no significant order.

\section{PDE5I plus VED}

The VED utilizes negative pressure to engorge the corpora cavernosa sinusoids with increased blood flow and can maintain penile rigidity via a constriction band. ${ }^{4}$ It is considered a second-line treatment for patients where PDE5Is are either contraindicated or ineffective. The VED is also very useful in the subset of men with prostate cancer who have undergone radical prostatectomy or pelvic radiation therapy. Recent animal studies suggest that the VED works regardless of pelvic neuropraxia from surgical manipulation and is tantamount to postprostatectomy penile rehabilitation by reducing hypoxia and corporeal fibrosis. ${ }^{5,6}$
Recently, the VED has been shown to have synergistic effects when used in conjunction with PDE5Is (Table 1). In a randomizedcontrolled study by Chen et al., 161 patients with ED were randomized to take either sildenafil or use a VED for a period of 2 months. Forty-one men were unhappy with monotherapy, and formed a selected combination cohort using both VED and sildenafil before sexual intercourse. Comparing pre- and post-treatment international index of erectile function (IIEF) scores, a significant increase in only the erectile function domain for both PDE5I and VED monotherapy arms was established. The men in the combination group, however, had significantly increased scores in all five domains of the IIEF questionnaire (erectile function, intercourse satisfaction, orgasmic function, sexual desire and overall satisfaction). Interestingly, the average age of patients in the combination arm was significantly younger than that of both groups unsatisfied with monotherapy. This could possibly indicate that younger men were more open to pursuing combinations to achieve a strong erection and less likely to compromise on the quality and efficacy of their ED treatment. This also indicates a systematic difference in these combination men which likely biases the results.

A study conducted by Raina et al. ${ }^{8}$ assessed 74 patients who had undergone radical prostatectomy for prostate cancer. This cohort was instructed to use the VED three times weekly for a total of 9 months beginning 4 weeks after surgery. Thirty-one out of 74 (42\%) patients were unsatisfied with this monotherapy and were offered $100 \mathrm{mg}$ of sildenafil to be taken before using the VED for intercourse. Twentyfour of these 31 (77\%) patients subsequently improved in the following domains: perceived rigidity, patient/spousal sexual satisfaction, successful penetration rate, overall IIEF score and return of nocturnal erection. Canguven et al. ${ }^{9}$ reported a case series of 69 patients who

Table 1 Phosphodiesterase-5 inhibitors (PDE5Is) plus vacuum erection device (VED)

\begin{tabular}{|c|c|c|c|c|c|c|c|c|c|}
\hline \multirow[t]{2}{*}{ Author (year) } & \multirow{2}{*}{$\begin{array}{l}\text { Study } \\
\text { design }\end{array}$} & \multirow{2}{*}{$\begin{array}{c}\text { No. of } \\
\text { patients }\end{array}$} & \multirow[t]{2}{*}{ Follow-up } & \multirow{2}{*}{\multicolumn{2}{|c|}{$\begin{array}{c}\text { Evaluation } \\
\text { questionnaire }\end{array}$}} & \multicolumn{3}{|c|}{ Results } & \multirow[t]{2}{*}{ Evidence level } \\
\hline & & & & & & PDE5I & VED & Combination & \\
\hline \multirow[t]{5}{*}{ Chen et al. $(2004)^{7}$} & \multirow[t]{5}{*}{ Cohort } & \multirow[t]{5}{*}{41} & \multirow[t]{5}{*}{2 months } & \multirow[t]{5}{*}{ IIEF } & Erectile function & $15.7 \pm 2.3$ & $17.1 \pm 1.9$ & $27.4 \pm 1.4^{*}$ & \multirow[t]{5}{*}{ Illb } \\
\hline & & & & & Intercourse satisfaction & $7.8 \pm 2.3$ & $8.1 \pm 1.7$ & $11.5 \pm 1.4^{*}$ & \\
\hline & & & & & Orgasmic function & $5.2 \pm 2.7$ & $5.6 \pm 2.5$ & $6.2 \pm 1.9 *$ & \\
\hline & & & & & Sexual desire & $6.6 \pm 1.7$ & $6.6 \pm 1.5$ & $7.5 \pm 0.8 *$ & \\
\hline & & & & & Overall satisfaction & $5.6 \pm 1.5$ & $5.7 \pm 1.1$ & $8.8 \pm 1.0 *$ & \\
\hline \multirow[t]{10}{*}{ Raina et al. $(2005)^{8}$} & \multirow[t]{10}{*}{ Cohort } & \multirow[t]{10}{*}{31} & \multirow{10}{*}{$\begin{array}{l}4.5 \text { months, } \\
\text { with at } \\
\text { least five } \\
\text { attempts }\end{array}$} & \multirow{6}{*}{$\begin{array}{l}\text { IIEF } \\
\text { VAS }\end{array}$} & Successful penetration rate (\%) & & 52 & 70 & \multirow[t]{10}{*}{ IV } \\
\hline & & & & & Patient rigidity score (0-100) & & 55 & 76 & \\
\hline & & & & & Partner rigidity score $(0-100)$ & & 59 & 82 & \\
\hline & & & & & Spousal satisfaction (\%) & & 55 & 64 & \\
\hline & & & & & Total IIEF-5 score & & $14.5 \pm 5.7$ & $18.5 \pm 8.2$ & \\
\hline & & & & & $\begin{array}{l}\text { Return of nocturnal } \\
\text { erections (\%) }\end{array}$ & & 0 & $29(7 / 24)$ & \\
\hline & & & & & & \multirow{4}{*}{\multicolumn{3}{|c|}{$\begin{array}{l}\text { Comments: } \\
77 \%(24 / 31) \text { of patients reported } \\
\text { improvement in penile rigidity and } \\
\text { sexual satisfaction. }\end{array}$}} & \\
\hline & & & & & & & & & \\
\hline & & & & & & & & & \\
\hline & & & & & & & & & \\
\hline \multirow[t]{7}{*}{ Canguven et al. (2009) ${ }^{9}$} & \multirow{7}{*}{$\begin{array}{l}\text { Case } \\
\text { series }\end{array}$} & \multirow[t]{7}{*}{69} & \multirow[t]{7}{*}{4 weeks } & IIEF & & \multirow{2}{*}{\multicolumn{2}{|c|}{$9.0 \pm 5.7$}} & \multirow[t]{2}{*}{$17.6 \pm 7.2^{*}$} & \multirow[t]{7}{*}{ IV } \\
\hline & & & & SEP & & & & & \\
\hline & & & & GPAS & & \multicolumn{3}{|c|}{ Comments: } & \\
\hline & & & & & & \multirow{4}{*}{\multicolumn{3}{|c|}{$\begin{array}{l}\text { With the combination therapy, } 79 \% \text { ( } 27 / \\
34), 70 \%(50 / 35) \text { and } 74 \% \text { ( } 31 / 42 \text { ) of } \\
\text { patients responded "yes" to SEP-2 and } \\
\text { SEP-3 and improvement to GPAS, } \\
\text { respectively. }\end{array}$}} & \\
\hline & & & & & & & & & \\
\hline & & & & & & & & & \\
\hline & & & & & & & & & \\
\hline
\end{tabular}


failed standard PDE5I therapy. The patients were then treated with VED and PDE5I for 4 weeks and the clinical efficacy of combination therapy was evaluated using IIEF, sexual encounter profile (SEP)-2, SEP-3 and the global patient assessment scale (GPAS). With the combination therapy, $79 \%$ and $70 \%$ of patients responded 'yes' to SEP-2 and SEP-3, respectively, 74\% of patients reported improvement on GPAS, and the IIEF was also significantly improved.

According to the Oxford Centre of Evidence-based Medicine's 'Levels of Evidence', ${ }^{10}$ there appears to be levels 2 and 4 evidence supporting higher patient satisfaction with combination PDE5I and VED. The VED clearly has an important role in combination therapy and can safely be used with few side effects or complications. In addition, it is a durable, reusable device that is relatively cost-effective. However, quality trials in multicenter settings with randomized controls and long-term follow-up are still in need.

\section{PDE5I plus intraurethral alprostadil}

Several articles in the past decade have investigated the combination of PDE5I and intraurethral alprostadil (or prostaglandin E1 (PGE1)), otherwise known as MUSE (Table 2). These two drugs act on different cavernosal pathways. PDE5I indirectly relaxes corporal smooth muscle via inhibiting the enzymatic breakdown of cyclic guanosine monophosphate by PDE5 and requires endogenous nitric oxide (NO). MUSE directly relaxes trabecular smooth muscle tissue via e-prostanoid receptors leading to an increase in cyclic adenosine monophosphate. Combining MUSE and PDE5I theoretically allows for therapeutic synergy via activating separate but interrelated pathways. Moreover, preclinical evidence shows that combination therapy can induce crosstalk between both pathways further potentiating treatment efficacy. ${ }^{11}$

Mydlo et al. ${ }^{12}$ presented data on a group of 120 men who individually failed both sildenafil and intraurethral alprostadil monotherapy. Combination therapy was initiated and efficacy was measured subjectively via the IIEF questionnaire. The erectile function domain with the use of combination therapy was significantly higher than that obtained with sildenafil and MUSE monotherapies. Combination therapy was safe with no patients dropping out secondary to side effects. Interestingly, the discontinuation rate of community clinic patients was approximately three times higher than private clinic patients. This perhaps points to additional variables involved in therapeutic compliance such as education level, socioeconomic status, medication costs and other psychosocial factors. In a case series of 28 patients, Nehra et al. ${ }^{13}$ achieved a $100 \%$ rate of erections deemed sufficient for penetration with combination treatment after patients failed sildenafil and/or alprostadil monotherapy. Using this regimen, no patients desired a transition to more invasive treatments such as ICI or penile prosthesis implantation. Eight of 28 patients decreased their sildenafil dose from 100 to $50 \mathrm{mg}$ with no change in erectile function. Impressively, a $100 \%$ compliance rate to combination therapy was obtained at an average 30 -month follow-up indicating the importance of good communication between physicians and patients to improve the success of treatment. This also reflects the selective nature of retrospective analysis. Another study replicated the abovementioned findings in the context of men undergoing bilateral nerve-sparing radical prostatectomy. Twenty-three men switched to combined therapy after PDE5I failure with an $83 \%$ response rate based on analysis of pre- and post-treatment IIEF-5 and $38 \%$ of patients reported increased visual analog scale scores. ${ }^{14}$

Based on the available retrospective case series, combination therapy with PDE5I and intraurethral alprostadil appears to be effective after monotherapy failure. The adverse effects (such as headache, dyspepsia, urethral burning, etc.) associated with this combination therapy are about the same as those seen with PDE5I or MUSE monotherapy. The success of this combination appears dependent upon the good communication between physician and patient in this motivated, selected group to ensure compliance and avoid unnecessary drop-out rates. Limitations to this therapeutic combination include lack of randomized controlled trials as well as overall drug cost.

\section{PDE5I plus ICI}

Triple-therapy ICI (usually with alprostadil, phentolamine and papaverine) functions by inducing an erection via the following cavernosal smooth muscle biochemical pathways: (i) elevation of the second messenger cyclic adenosine monophosphate via alprostadil; (ii) non-selective inhibition of phosphodiesterases by papaverine; and

Table 2 Phosphodiesterase-5 inhibitors (PDE5Is) plus intraurethral alprostadil

\begin{tabular}{|c|c|c|c|c|c|c|c|c|}
\hline \multirow[t]{2}{*}{ Author (year) } & \multirow[t]{2}{*}{ Study design } & \multirow[t]{2}{*}{ No. of patients } & \multirow[t]{2}{*}{ Follow-up } & \multirow{2}{*}{$\begin{array}{c}\text { Evaluation } \\
\text { questionnaire }\end{array}$} & \multicolumn{3}{|c|}{ Results } & \multirow[t]{2}{*}{ Evidence level } \\
\hline & & & & & Sildenafil & Alprostadil & Combination & \\
\hline $\begin{array}{l}\text { Mydlo et al. } \\
(2000)^{12}\end{array}$ & Case series & 120 & 18 months & IIEF-EF & $\begin{array}{l}\text { 19.8 } \pm 1.8 \\
\text { Comments: } \\
\text { 1. All } 120 p \\
\text { 2. High disc } \\
\text { on the cli }\end{array}$ & $\begin{array}{l}15.2 \pm 1.6 \\
\text { ailed both mo } \\
\text { tion rate ( } 7.6 \\
\text { ting of the pat }\end{array}$ & $\begin{array}{l}24.1 \pm 2.0 * \\
\text { s. } \\
\text { depending }\end{array}$ & IV \\
\hline $\begin{array}{c}\text { Nehra et al. } \\
(2002)^{13}\end{array}$ & Case series & 28 & 30 months & $\mathrm{GAQ}$ & $\begin{array}{l}\text { Comments: } \\
\text { 1. All } 28 \mathrm{pa} \\
\text { monother } \\
\text { 2. } 100 \% \mathrm{im} \\
\text { monother } \\
\text { 3. } 100 \% \mathrm{co}\end{array}$ & $\begin{array}{l}\text { iled either sild } \\
\text { ent on GAQ in } \\
\text { e rate to com }\end{array}$ & $\begin{array}{l}\text { or alprostadil } \\
\text { on arm from } 0 \% \text { in } \\
\text { erapy at } 30 \text { months. }\end{array}$ & IV \\
\hline $\begin{array}{l}\text { Raina et al. } \\
(2005)^{14}\end{array}$ & Case series & 23 & $\begin{array}{c}\text { at least four } \\
\text { attempts }\end{array}$ & $\begin{array}{l}\text { IIEF } \\
\text { VAS }\end{array}$ & $\begin{array}{l}\text { 13.2 } \pm 5.8 \\
\text { Comments: } \\
\text { 1. All patien } \\
\text { 2. } 83 \% \text { ( } 19 \\
\text { 3. } 38 \% \text { incr }\end{array}$ & $\begin{array}{l}\text { VSRP. } \\
\text { ort improvem } \\
\text { VAS with con }\end{array}$ & ile function. & IV \\
\hline
\end{tabular}


(iii) $\alpha$-adrenergic receptor antagonism by phentolamine. ${ }^{15}$ Alternatively, sildenafil acts upon the NO/cyclic guanosine monophosphate pathway. It is plausible that triple-agent ICI pathways in combination with PDE5Is can act synergistically through different mechanisms of action.

Two studies are available that use ICI in combination with PDE5I for therapy (Table 3). McMahon et al. ${ }^{16}$ reported a case series including 93 patients with chronic ED who failed ICI therapy. ICI was discontinued, and salvage sildenafil was offered and found to be effective with increased IIEF questions 3 and 4 scores in roughly one-third (34\%) of these non-responders. The remaining non-responders switched to a combination of ICI triple-therapy plus a PDE5I. Forty-eight percent of patients positively responded to the dual therapy with increased IIEF questions 3 and 4 scores. Despite favorable results for salvage combination, ICI plus sildenafil caused an increase in the number of adverse effects per patient in comparison to the monotherapy groups. The authors concluded that caution should be used in patients receiving ICI/PDE5I combinations and blood pressure challenge studies could be helpful in selecting the ideal ICI/PDE5I combination therapy patients. However, ICI acts locally and should not affect systemic blood pressure for the given dosage. The somewhat increased systemic adverse effects (dizziness and syncope) in combination group compared to PDE5I monotherapy (no statistical analysis performed) cannot be simply explained by additional ICI.

In a prospective case series, 22 patients after radical prostatectomy were started on early combination of sildenafil and ICI (either with alprostadil only or with triple agents) upon hospital discharge. ${ }^{17}$ At an average 6-month follow-up, patients on combination therapy had significantly better IIEF scores compared to monotherapy either with sildenafil or ICI. Also, the authors believed that the combination treatment allowed for a lower dose of ICI to minimize penile discomfort from injection, particularly with alprostadil.

Physiological evidence exists for the use of combination sildenafil and ICI therapy. Park et al. ${ }^{18}$ demonstrated the benefit of combination sildenafil and triple-agent ICI for pharmacological erection testing with color Doppler ultrasonography. They found that the best results obtained regarding hemodynamic changes were seen in the combination arm; furthermore, cyclic guanosine monophosphate and cyclic adenosine monophosphate production from the cavernosum were the highest with the use of sildenafil plus triple-agent ICI when compared with single-agent ICI, triple-agent ICI or sildenafil plus single-agent ICI.

ICI is highly effective for treatment of ED. Its role as combination modality with PDE5I, however, has yet to be defined for refractory cases. Clinically, the combination of PDE5I and ICI may require additional attention for dose optimization and management of side effects. The risk of prolonged erection or even priapism may be increased with combination PDE5I and ICI, though available studies with this combination therapy did not show or emphasize this concern. It is also difficult to make dosage adjustments for patients using combination therapy. Therefore, in addition to developing a well-designed clinical trial, future studies should focus on optimizing dosing to avoid local and systemic adverse events.

\section{PDE5I plus androgen supplementation}

Early paradigms linked low to low-normal levels of androgens with a decrease in sexual libido. In the 1990s, animal and human studies showed that androgens not only worked centrally, but also played a direct role in peripheral physiological erections via effects on the corpora cavernosa. In rats, castration caused decreased nitric oxide synthase activity and dampened erectile function to pelvic nerve stimulation. ${ }^{19}$ Further studies on humans have associated low free testosterone levels with impaired cavernous vasodilation. ${ }^{20}$

ED and hypogonadism are two disease processes often found concurrently in the clinic setting. This subset of patients can be unresponsive to PDE5I monotherapy. It is reasonable to postulate that the addition of androgen supplementation to PDE5I use would enhance

Table 3 Phosphodiesterase-5 inhibitors (PDE5Is) plus intracavernous injection (ICI)

\begin{tabular}{|c|c|c|c|c|c|c|c|c|c|}
\hline \multirow[t]{2}{*}{ Author (year) } & \multirow[t]{2}{*}{$\begin{array}{l}\text { Study } \\
\text { design }\end{array}$} & \multirow[t]{2}{*}{$\begin{array}{l}\text { No. of } \\
\text { patients }\end{array}$} & \multirow[t]{2}{*}{ Follow-up } & \multirow{2}{*}{\multicolumn{2}{|c|}{$\begin{array}{l}\text { Evaluation } \\
\text { questionnaire }\end{array}$}} & \multicolumn{3}{|c|}{ Results } & \multirow[t]{2}{*}{$\begin{array}{c}\text { Evidence } \\
\text { level }\end{array}$} \\
\hline & & & & & & PDE5I & $\mathrm{ICl}$ & Combination & \\
\hline $\begin{array}{l}\text { McMahon et al. } \\
\left(_{(1999)^{16}}\right.\end{array}$ & Case series & 93 & $\begin{array}{c}\text { Every } 4 \text { weeks for } \\
3.5 \text { months }\end{array}$ & IIEF & $\begin{array}{l}\text { Q3 score } \\
\text { Q4 score }\end{array}$ & \multicolumn{3}{|c|}{$\begin{array}{l}\text { Comments: } \\
\text { 1. All } 93 \text { patients were ICI failure. } \\
\text { 2. } 34 \% \text { (32/93) patients achieved erections sufficient } \\
\text { for intercourse with salvage sildenafil. } \\
\text { 3. } 48 \%(29 / 61 \text { ) responded to combined therapy } \\
\text { (sildenafil and ICI) with erections sufficient for } \\
\text { intercourse. } \\
\text { 4. Overall, } 66 \% \text { (61/93) ICI failures responded to } \\
\text { salvage sildenafil monotherapy or combined } \\
\text { therapy. } \\
\text { 5. Side effects: } 31 \% \text { for ICI, } 37 \% \text { for salvage Sildenafil } \\
\text { and } 49 \% \text { with combination therapy. }\end{array}$} & IV \\
\hline $\begin{array}{l}\text { Nandipati et al. } \\
(2006)^{17}\end{array}$ & Case series & 22 & 6 months & $\begin{array}{l}\text { IIEF } \\
\text { CDU }\end{array}$ & & $\begin{array}{r}\text { 10.5 } \pm 1.8 \\
\text { Comme } \\
\text { 1. } 42.9 \\
\text { RP. } \\
\text { 2. Early } \\
\text { lowe }\end{array}$ & $\begin{array}{l}19.4 \pm 2.4 * \\
\text { ouire combi } \\
\text { on therapy wi }\end{array}$ & $\begin{array}{l}22.1 \pm 0.3^{* *} \\
\text { In therapy after } \\
\text { Idenafil allowed a }\end{array}$ & IV \\
\hline
\end{tabular}

Abbreviations: CDU, color doppler ultrasonography; IIEF, international index of erectile function; RP, radical prostatectomy.

$* P<0.05$, compared with PDE5I monotherapy. ${ }^{* *} P<0.05$, compared with two monotherapies. 
Table 4 Phosphodiesterase-5 inhibitors (PDE5Is) and androgen supplementation

\begin{tabular}{|c|c|c|c|c|c|c|}
\hline Author (year) & $\begin{array}{l}\text { Study } \\
\text { design }\end{array}$ & $\begin{array}{l}\text { No. of } \\
\text { patients }\end{array}$ & Follow-up & $\begin{array}{l}\text { Evaluation } \\
\text { questionnaire }\end{array}$ & Results & $\begin{array}{c}\text { Evidence } \\
\text { level }\end{array}$ \\
\hline $\begin{array}{l}\text { Aversa et al. } \\
(2003)^{20}\end{array}$ & RCT & 20 & 1 month & IIEF & $\begin{array}{l}\text { 1. All patients were sildenafil failure ( } 100 \mathrm{mg} \text { six consecutive attempts) } \\
\text { with low-normal } \mathrm{T}(12.8 \pm 2.1 \mathrm{nmol} \text { ) and free } \mathrm{T}(260 \pm 18 \mathrm{pmol} \text { ). } \\
\text { 2. Transdermal ( } 5 \mathrm{mg} \text { ) or placebo patches (daily) and } 100 \mathrm{mg} \text { Viagra on } \\
\text { demand for } 1 \text { month with sexual activity at least twice weekly. } \\
\text { 3. Significant improvements of IIEF ( } 21.8 \pm 2.1 \text { versus } 14.4 \pm 1.4 \text {, } \\
P<0.05 \text { ) and arterial flow by penile Doppler study were seen } \\
\text { in combination groups. }\end{array}$ & $\|$ \\
\hline $\begin{array}{l}\text { Greenstein et al. } \\
(2005)^{22}\end{array}$ & $\begin{array}{l}\text { Case } \\
\text { series }\end{array}$ & 49 & 6 months & IIEF; GAQ & $\begin{array}{l}\text { 1. All patients had total } \mathrm{T}<400 \mathrm{mg} \mathrm{dl}^{-1} \text { and were treated with } \\
\mathrm{T} \text {-Gel for } 6 \text { months. } \\
\text { 2. } 31 / 49 \text { had improved } \mathrm{EF} \text { scores (from } 13.6 \pm 1.9 \text { to } 27.0 \pm 0.8 \text { ) } \\
\text { and GAQ improvement. } \\
\text { 3. } 17 / 49 \text { had } \mathrm{EF} \text { scores }<26 \text { who were treated with combination of } \\
\mathrm{T} \text {-Gel and sildenafil and the } \mathrm{EF} \text { scores became normal and } \mathrm{GAQ} \text { improved. }\end{array}$ & IV \\
\hline $\begin{array}{l}\text { Rosenthal et al. } \\
(2006)^{23}\end{array}$ & $\begin{array}{l}\text { Case } \\
\text { series }\end{array}$ & 24 & 16 weeks & $\begin{array}{l}\text { Custom-made } \\
\text { erectile scale } \\
\qquad(1-5)\end{array}$ & $\begin{array}{l}\text { 1. All } 24 \text { patients were sildenafil failure ( } 100 \mathrm{mg} \text { at least three } \\
\text { attempts in } 3 \text { months) with } \mathrm{T}<400 \mathrm{mg} \mathrm{dl^{-1 }} \text {. } \\
\text { 2. } 1 \% \mathrm{~T} \text {-Gel for } 4 \text { weeks, then sildenafil was added on } \\
\text { demand and evaluated at week } 16 \text {. } \\
\text { 3. } 92 \% \text { (22/24) of patients reported improved potency capable of } \\
\text { penetration with erection quality score of } 4 \text { or greater. }\end{array}$ & IV \\
\hline $\begin{array}{c}\text { Yassin et al. } \\
(2006)^{24}\end{array}$ & RCT & 69 & 10 weeks & IIEF & $\begin{array}{l}\text { 1. All patients were tadalafil failure (poor EF score and persistent } \\
\text { dissatisfaction) with } T \leqslant 3.4 \mathrm{ng} \mathrm{m}^{-1} \text {. } \\
\text { 2. Testogel started for } 10 \text { weeks with tadalafil restart at } 4 \text { weeks } \\
\text { ( } 20 \mathrm{mg} \text { twice/week) in one group. } \\
\text { 3. IIEF was improved in both T monotherapy and combination groups, } \\
\text { but greater improvement in combination. }\end{array}$ & II \\
\hline
\end{tabular}

Abbreviations: $\mathrm{EF}$, erectile function; GAQ, global assessment question; IIEF, international index of erectile function; RCT, randomized controlled trial; RT, randomized trial; $\mathrm{T}$, testosterone.

sexual activity in hypogonadal men with ED. Indeed, there are clinical trials using the combination of PDE5I with androgen supplementation as summarized in Table 4.

Aversa et $a l^{20}$ conducted a small prospective randomized trial in patients with arteriogenic ED and total and free testosterone levels in the lower quartile of normal range who failed sildenafil monotherapy. These patients were treated with either placebo plus PDE5I or testosterone supplement plus PDE5I. After 1 month of treatment, combination users had significant increases in arterial inflow as measured by Doppler Ultrasound as well as in IIEF score. Shabsigh et al. ${ }^{21}$ randomized 75 hypogonadal men unresponsive to sildenafil monotherapy into daily placebo or $1 \%$ testosterone gel (T-Gel) in combination with sildenafil. Seventy patients completed the study for final analysis. In as early as 4 weeks, the PDE5I plus T-Gel group had twice as many responders as the placebo group, although this difference lost significance over time.

A case series by Greenstein et al. ${ }^{22}$ reported that 17 of 49 hypogonadal patients who had failed testosterone monotherapy had significant improvement of their erectile function using IIEF questionnaire measurements after combination with sildenafil. All 49 men answered 'yes' to being satisfied with their erections with combined therapy using the global assessment question (GAQ). In another case series, 24 hypogonadal sildenafil non-responders were given 4 weeks of T-Gel followed by the addition of a PDE5I for 12 weeks. Ninety-two percent of men reported an increase in erectile quality score, although the study lacked a control group and failed to use a validated questionnaire. ${ }^{23}$ Yassin et al. ${ }^{24}$ conducted a randomized uncontrolled study in 69 hypogonadal tadalafil non-responders and concluded that androgen supplementation alone was sufficient in increasing erectile function as monotherapy in these patients. However, adding PDE5I again potentiated the erectile function domain scores with additive effect. The authors also discovered that a period of at least 4 weeks of androgen supplementation might be necessary to obtain a benefit when combining treatment modalities.

Overall, these studies did not identify any additional adverse effects to discourage combined treatment. However, caution should be taken regarding potential infertility caused by long-term exogenous androgen replacement in young men. Also, the quality of these trials is questionable due to study limitations, short follow-up periods and small patient numbers. The mechanism of additional androgen replacement to PDE5I in the treatment of ED in patients with low or low-normal testosterone is not clear since decreased testosterone affects libido more than it affects the erection unless patients have a castrated level of androgen. Currently there is not sufficient evidence to support routine use of androgen supplementation plus PDE5I for patients with low to low-normal testosterone levels and ED.

\section{PDE5I plus $\alpha$-adrenergic receptor antagonist}

Male sexual dysfunction and lower urinary tract symptoms (LUTS) are both highly prevalent in the aging, Westernized male 
population. ${ }^{25}$ Anecdotal evidence based on clinical practice has indicated that treatment of LUTS with $\alpha$-adrenergic receptor antagonists also provides ED symptom improvement; alternatively, ED treatment with PDE5Is may partially relieve symptoms of benign prostatic hyperplasia $(\mathrm{BPH})$. The perceived connection between both disease processes and their respective treatment modalities has been validated in the literature. ${ }^{26}$

Experimental animal models have directly linked $\alpha$-adrenergic receptor antagonists to relaxation of cavernosal smooth muscle. ${ }^{27,28}$ Researchers also have found that $\alpha$-adrenergic receptor antagonists potentiates corporal vasodilators dependent on cyclic nucleotide second-messengers. ${ }^{28}$ Applying these findings to human models, Oger et al..$^{29}$ used cavernosal and prostatic tissue specimens from patients who underwent penile or prostatic surgery and demonstrated that combining sildenafil with doxazosin in tissue baths significantly increased overall tissue relaxation. This discovery has been the impetus for several randomized studies attempting to demonstrate the efficacy and safety of combining PDE5Is with $\alpha$-adrenergic receptor antagonists to treat complex ED (Table 5).

de Rose et al. ${ }^{30}$ randomized 28 sildenafil non-responders to either the combination sildenafil plus doxazosin experimental group or the sildenafil plus placebo control group. The combination arm had a significantly higher mean IIEF score post-treatment in comparison with the placebo group. Another pilot study ${ }^{31}$ examined 62 men with both LUTS and ED and randomized them into three groups: sildenafil monotherapy, alfuzosin monotherapy or combination therapy with sildenafil plus alfuzosin. After a 12-week period, relative IIEF score increases were greatest in the combination arm (58.6\% improvement) versus either monotherapy group (16.7\% for alfuzosin and $49.7 \%$ for sildenafil). Also, relative international prostate symptom scores (IPSS) were the lowest in the combination arm (a 24\% decrease from baseline), which supports other clinical studies showing sildenafil's independent positive effect on IPSS reduction in men with benign prostatic hyperplasia. ${ }^{32,33}$ Liguori et al. ${ }^{34}$ examined tadalafil and alfuzosin in 66 men with LUTS and ED. As seen in earlier studies, combination therapy again showed benefits in comparison to monotherapy in treating both of these disease processes.

The efficacy in the literature of combining PDE5Is with $\alpha$-adrenergic receptor antagonists suggests a synergistic method of treating ED refractory to monotherapy. More specifically, these initial pilot studies indicate that combining these two treatment modalities is ideally suited and most efficacious in men with concurrent ED and LUTS. However, some degree of caution is advised with using PDE5I in conjunction with $\alpha$-adrenergic receptor antagonists to avoid any adverse hemodynamic effect. ${ }^{26}$

\section{PDE5I plus other medications}

In the last decade, researchers have introduced many novel therapies combined with PDE5I that could help modify current clinical practice. Listed in Table 6 is a summary of the preliminary findings involving the newest medical combination treatments with PDE5I.

PDE5I monotherapy is often less efficacious in diabetics. ${ }^{35,36}$ Gentile et al. ${ }^{37}$ were the first to administer propionyl-L-carnitine (PLC), a naturally occurring substance in mammalian energy metabolism, to patients with both ED and diabetes. Men randomized to the PDE5I/PLC combination group scored significantly higher on the IIEF questionnaire and had more positive responses to the global efficacy question (GEQ: has treatment improved your erection?). A follow-up study showed significantly higher IIEF scores in men using combination PDE5I plus PLC and acetyl-L-carnitine when compared with PDE5I monotherapy in patients undergoing bilateral nervesparing radical prostatectomy for prostate cancer. ${ }^{38}$ It is currently thought that both PLC and acetyl-L-carnitine function as antifibrotic and antioxidative compounds.

A pilot study by Herrmann et al. ${ }^{39}$ focused on men with both ED and coronary artery disease and found that combination therapy with PDE5I and atorvastatin (a statin to decrease blood cholesterol levels by inhibiting the liver enzyme HMG Co-A reductase) yielded significantly higher IIEF scores in comparison with the placebo arm. PT141, a melanocortin analog, has been used in several phases I and II trials and may help treat ED by acting upstream on the NO pathway. ${ }^{40}$ Its intranasal administration along with simultaneous PDE5I use demonstrated a statistically significant increased erectile response as documented by RigiScan when compared with placebo groups. ${ }^{41} \mathrm{~A}$ pilot study combining trazodone (a non-tricyclic antidepressant) and sildenafil has yielded promising results in PDE5I monotherapy nonresponders; however, study limitations include small sample size and lack of a control group. ${ }^{42}$ Pentoxifylline, a methylxanthine derivative used in peripheral arterial disease, now believed to have an antifibrotic effect, has been effectively combined with PDE5I to significantly

Table 5 Phosphodiesterase-5 inhibitors (PDE5Is) plus $\alpha$-adrenergic receptor antagonists

\begin{tabular}{|c|c|c|c|c|c|c|c|c|}
\hline Author (year) & \multirow{2}{*}{$\begin{array}{l}\text { Study } \\
\text { design }\end{array}$} & $\begin{array}{l}\text { No. of } \\
\text { Patients }\end{array}$ & \multirow[t]{2}{*}{ Follow-up } & \multirow{2}{*}{$\begin{array}{l}\text { Evaluation } \\
\text { Questionnaire }\end{array}$} & \multicolumn{3}{|c|}{ Results } & \multirow[t]{2}{*}{ Evidence level } \\
\hline de Rose et al. $(2002)^{30}$ & & 28 & & & & $\begin{array}{l}\text { Sildenafil } \\
13.5 \pm 4.1\end{array}$ & $\begin{array}{l}\text { Combination } \\
20.86 \pm 3.2^{*}\end{array}$ & \\
\hline & & & & & \multirow{3}{*}{\multicolumn{3}{|c|}{$\begin{array}{l}\text { Comments: } \\
\text { 1. All } 28 \text { patients were sildenafil failure. } \\
\text { 2. } 78.6 \%(11 / 14) \text { patients with doxazosin daily and } \\
\text { sildenafil on demand showed a significant IIEF } \\
\text { increase compared to sildenafil on demand only group. }\end{array}$}} & \\
\hline & & & & & & & & \\
\hline & & & & & & & & \\
\hline & & & & & Alfuzosin & PDE5I & Combination & \\
\hline \multirow[t]{2}{*}{ Kaplan et al. $(2007)^{31}$} & $\mathrm{RCT}$ & 62 & 12 weeks & IIEF-EF, & $20.3 \pm 5.2$ & $21.4 \pm 5.7$ & $25.7 \pm 4.9$ & $\|$ \\
\hline & & & & IPSS & $14.6 \pm 3.7$ & $14.9 \pm 4.2$ & $13.5 \pm 4.2$ & \\
\hline \multirow[t]{4}{*}{ Liguori et al. (2009) $)^{34}$} & $\mathrm{RCT}$ & 66 & 12 weeks & IIEF-EF, & $16.0 \pm 4.6$ & $18.8 \pm 4.8$ & $19.9 \pm 4.8$ & II \\
\hline & & & & IPSS & $10.5 \pm 3.6$ & $12.5 \pm 5.6$ & $9.0 \pm 4.0$ & \\
\hline & & & & & \multicolumn{3}{|c|}{ Comments: } & \\
\hline & & & & & \multicolumn{3}{|c|}{$\begin{array}{l}\text { The greatest improvements of IIEF-EF and IPSS are observed } \\
\text { with the combination therapy compared to the baseline. }\end{array}$} & \\
\hline
\end{tabular}


Table 6 Phosphodiesterase-5 inhibitors (PDE5Is) and other medications

\begin{tabular}{|c|c|c|c|c|c|c|c|}
\hline Author (year) & $\begin{array}{l}\text { Study } \\
\text { design }\end{array}$ & $\begin{array}{l}\text { No. of } \\
\text { patients }\end{array}$ & Follow-up & $\begin{array}{l}\text { Evaluation } \\
\text { questionnaire }\end{array}$ & Combination modality & Results & $\begin{array}{l}\text { Evidence } \\
\text { level }\end{array}$ \\
\hline $\begin{array}{l}\text { Gentile et al. } \\
(2004)^{37}\end{array}$ & RCT & 40 & 24 weeks & IIEF & Sildenafil/PLG & $\begin{array}{l}\text { Statistically significant increase } \\
\text { of IIEF in combination group }\end{array}$ & $\|$ \\
\hline $\begin{array}{l}\text { Herrmann et al. } \\
(2005)^{39}\end{array}$ & RCT & 12 & 12 weeks & IIEF & Sildenafil/atorvastatin & $\begin{array}{l}\text { Statistically significant increase } \\
\text { in mean IIEF in combination arm }\end{array}$ & ॥ \\
\hline $\begin{array}{l}\text { Taneja et al. } \\
(2007)^{42}\end{array}$ & Case series & 18 & 2 weeks & EDIS & Sildenafil/trazodone & $\begin{array}{l}66.7 \% \text { of patients had considerable EDIS } \\
\text { increase with addition of trazodone }\end{array}$ & IV \\
\hline $\begin{array}{l}\text { Osdal et al. } \\
(2008)^{43}\end{array}$ & Case series & 68 & 8 weeks & IIEF & Sildenafil/pentoxifylline & $\begin{array}{l}\text { Statistically significant increase in mean } \\
\text { IIEF score in combination compared } \\
\text { with sildenafil monotherapy }\end{array}$ & IV \\
\hline $\begin{array}{l}\text { Kondoh et al. } \\
(2008)^{44}\end{array}$ & Case series & 9 & $<1$ month & IIEF & PDE5Is/vitamin E & $\begin{array}{l}\text { Increased IIEF score with } \\
\text { combination arm }\end{array}$ & IV \\
\hline
\end{tabular}

Abbreviations: ALC, acetyl-L-carnitine; EDIS, erectile dysfunction intensity scale; IIEF, international index of erectile function; PLG, propionyl-L-carnitine; PT-141, melanotan-II metabolite.

increase IIEF scores when compared to PDE5I monotherapy. ${ }^{43} \mathrm{~A}$ small study of PDE5I non-responders were given at least 1 month of $\alpha$-tocopherol (vitamin E, an important antioxidant that neutralizes free radicals in the body) combined with sildenafil. The sample size was small, but favorable subjective change was noted in eight of nine patients. $^{44}$

\section{Miscellaneous combinations}

For completeness of the review, the following miscellaneous ED combination treatments are found in the literature:

- Lebret et al. ${ }^{45}$ combined yohimbine (an alkaloid that possesses adrenergic-antagonism properties) with L-arginine in a threeway crossover randomized controlled trial and found that the combination group had significant increases in IIEF erectile domain scores and was most effective in mild to moderate ED cases with baseline sexual health inventory for men scores of greater than or equal to 14 . It is proposed that this combination takes advantage of the synergistic mechanisms between $\mathrm{L}$-arginine and yohimbine: increased NO availability via increased upstream precursors versus peripheral action via alpha-2 adrenoreceptor blockade and increased NO release from penile nerves, respectively.

- In patients with ED from cavernosometry-proven veno-occlusive dysfunction, $93.8 \%$ of patients receiving combination therapy, consisting of penile venous stripping surgery plus postoperative sildenafil, were satisfied with their improvement postoperatively; the control group was simply re-introduced to sildenafil monotherapy and only $12.7 \%$ of patients perceived satisfactory erectile function. ${ }^{46}$ This study lacked a true placebo treatment to combine with sildenafil in the control group, and also lacked much-needed objective data of comparing pre- and postoperative erection improvement.

- Perimenis et al. ${ }^{47}$ investigated the concurrent effects of ED and obstructive sleep apnea. Forty patients with these dual comorbidities were randomized to combination continuous positive airway pressure plus PDE5I versus continuous positive airway pressure alone. The combination arm had a significantly higher successful intercourse rate compared with continuous positive airway pressure monotherapy and PDE5I monotherapy.
- Two recent studies have combined sildenafil plus psychosocial treatments in the form of sex therapy. Results show at least a partial response to the combined treatment in regards to erectile function and overall sexual satisfaction. ${ }^{48,49}$

- John et al. ${ }^{50}$ conducted the only known objective study of combination therapy with intraurethral PGE1 plus VED. A cohort of 19 patients with ED underwent measurements of penile length and diameter while flaccid, following use of VED, and finally after combination with PGE1. Mean increases in diameter and length with VED monotherapy were 4 and $26 \mathrm{~mm}$, respectively. Twenty micrograms of liquid PGE1 instilled intraurethrally before VED use resulted in mean increases of 7 and $36 \mathrm{~mm}$, respectively. Both mean measurement increases by combination therapy were statistically significant, giving rare objective evidence of ED combination therapy efficacy.

- An early study in 1988 identified the complementary benefit of ICI and VED by measuring patient's penile buckling pressure, a measurement of penile rigidity. Twenty-one of 22 men who originally had a low buckling pressure after ICI improved their erection parameters with the immediate addition of VED. ${ }^{51}$ Chen et al. ${ }^{52}$ found similar results in a cohort of 10 men that were non-responders to both ICI and VED monotherapy. This group combined ICI with VED and achieved statistically significant mean increases in length, circumference and buckling pressure as compared with monotherapy. VED plus ICI, although often described as cumbersome, appears to be an effective non-surgical ED solution.

- Failing first- and second-line therapies for ED are indications for implantation of a penile prosthesis. Inflatable penile prostheses (IPPs) carry the highest patient and partner satisfaction rates of all ED treatment modalities. A large, multicenter trial documented a maintained mechanical function rate of $82.5 \%$ at median follow-up of 4 years and $87.1 \%$ of men had erections satisfactory for sexual intercourse at a mean of 84.9 months. ${ }^{53}$ Despite the ease of achieving a strong erection, disadvantages to IPPs include a lack of mechanical glans engorgement. This can lead to dissatisfaction due to a partially flaccid or 'cold penis'. Early reports of combined intraurethral alprostadil with IPP showed promise for increased glans tumescence and even subjective penile girth increases. There was a high dropout rate, however, due to penile pain from intraurethral therapy. ${ }^{54,55}$ With ED treatment success rates higher for PDE5I compared with 
intraurethral PGE1, Mulhall et al. ${ }^{56}$ investigated the PDE5I/IPP combination. Thirty-two patients were given combination therapy and all patients reported some degree of glans engorgement. Additionally, all four IIEF satisfaction domain questions carried significantly higher scores in the combination group. Although this study had no objective criteria for glans engorgement, significant increases in patient satisfaction in the combination arm suggest a benefit of PDE5I/IPP therapy in men complaining of a flaccid glans penis with IPP monotherapy. An earlier, smaller study comprising of 12 men with IPP who were offered sildenafil had similar results. ${ }^{57}$

- Soderdahl et al. ${ }^{58}$ published the only known article discussing the combination of penile prosthesis with the VED. Twelve patients who had undergone implantation of a penile prosthesis tried concomitant VED therapy. A follow-up telephone survey collected patient opinions regarding efficacy, satisfaction and side effects. All patients reported increased rigidity and satisfaction, and 11 of 12 noticed improved length and girth. Combination therapy was deemed safe for the group regardless of using a semirigid or inflatable prosthesis. This small survey, although subjective and retrospective, identifies an additional option either for patients unsatisfied with the quality of erection with prosthesis, or for those who are awaiting prosthesis revision secondary to malfunction.

The abovementioned studies represent hypothesis generating results regarding new treatment combinations. It is important to note that the collected data are far from complete, and continued research efforts will help shed light on safe and useful combinations for complex ED patients who fail first-line monotherapy.

\section{CONCLUSION}

The efficacy of combination therapy appears encouraging at this time and likely represents the foundation for difficult-to-treat ED now and in the near future. In the recent past, PDE5I non-responders had few alternative non-surgical options for their ED management. Based on a review of the literature, second-line ED treatment algorithms must now be modified to include the option of implementing several encouraging combination treatments shown to be quite efficacious in preliminary testing. The combination therapy choice appears to be logical based on the etiology, such as in patients with ED associated with LUTS, hypogonadism, depression and sleep apnea. Caution must be advised, however, as the majority of combination therapy studies in the last decade have numerous limitations which introduce bias and lower the quality of the evidence. Regardless of limitations, present combination therapy findings provide a solid foundation for future studies in complex ED management.

\section{COMPETING FINANCIAL INTERESTS}

The authors declare no competing financial interests.

1 Lue T, Broderick G. Evaluation and nonsurgical management of erectile dysfunction and premature ejaculation. In: Walsh PC, Retik AB, Vaughan ED, Wein AJ, editors. Campbell's Urology, 9th ed., Chapter 22. Philadelphia, , PA: WB Saunders; 2006. 750-87.

2 McKinlay JB. The worldwide prevalence and epidemiology of respective PDEs, could achieve greater enhance- erectile dysfunction. Int J Impot Res 2000; 2(Suppl 4): S6-11.

3 Sommer F, Engelmann U. Future options for combination therapy in the management of erectile dysfunction in older men. Drugs Aging 2004; 21: 555-64

4 Yuan J, Hoang AN, Romero CA, Lin H, Dai Y et al. Vacuum therapy in erectile dysfunction—science and clinical evidence. Int J Impot Res 2010; 22: 211-9.
5 Yuan J, Westney OL, Wang R. Design and application of a new rat specific vacuum erectile device for penile rehabilitation research. J Sex Med 2009; 6: 3247-53.

6 Yuan J, Lin H, Li P, Zhang R, Luo A et al. Molecular mechanisms of vacuum therapy in penile rehabilitation: a novel animal study. Eur Urol 2010; 58: 773-80.

7 Chen J, Sofer M, Kaver I, Matzkin H, Greenstein A. Concomitant use of sildenafil and a vacuum entrapment device for the treatment of erectile dysfunction. J Urol 2004; 171: 292-5.

8 Raina R, Agarwal A, Allamaneni SS, Lakin MM, Zippe CD. Sildenafil citrate and vacuum constriction device combination enhances sexual satisfaction in erectile dysfunction after radical prostatectomy. Urology 2005; 65: 360-4.

9 Canguven O, Bailen J, Fredriksson W, Bock D, Burnett AL. Combination of vacuum erectile device and PDE5 inhibitors as salvage therapy in PDE5 inhibitor nonresponders with erectile dysfunction. J Sex Med 2009; 6: 2561-7.

10 Levels of Evidence and Grades of Recommendation. Centre for Evidence-Based Medicine. http://www.cebm.net/?o=1025 (accessed 12 December 2010).

11 Kim NN, Huang Y, Moreland RB, Kwak SS, Goldstein I et al. Cross-regulation of intracellular cAMP and CGMP in cultured human corpus cavernosum smooth muscle cells. Mol Cell Biol Res Commun 2000; 4: 10-4.

12 Mydlo JH, Volpe MA, MacChia RJ. Results from different patient populations using combined therapy with alprostadil and sildenafil: predictors of satisfaction. BJU Int 2000; 86: 469-73.

13 Nehra A, Blute ML, Barrett DM. Rationale for combination therapy of intraurethral prostaglandin E1 and sildenafil in the salvage of erectile dysfunction patients desiring noninvasive therapy. Int J Impot Res 2002; 4(Suppl 1): S38-42.

14 Raina R, Nandipati KC, Agarwal A, Mansour D, Kaelber DC et al. Combination therapy: medicated urethral system for erection enhances sexual satisfaction in sildenafi citrate failure following nerve-sparing radical prostatectomy. J Androl 2005; 26 757-60.

15 Moore CR, Wang R. Pathophysiology and treatment of diabetic erectile dysfunction. Asian J Androl 2006; 8: 675-84.

16 McMahon CG, Samali R, Johnson H. Treatment of intracorporeal injection nonresponse with sildenafil alone or in combination with triple agent intracorporeal injection therapy. J Urol 1999; 162: 1992-8.

17 Nandipati K, Raina R, Agarwal A, Zippe CD. Early combination therapy: intracavernosal injections and sildenafil following radical prostatectomy increases sexual activity and the return of natural erections. Int J Impot Res 2006; 18: 44651

18 Park JK, Park JS, Jeon SB, Cui WS, Kim SZ et al. Why a combined intracavernosal injection with trimix and oral sildenafil is reliable therapy in the ultrasonographic evaluation of erectile dysfunction. BJU Int 2008; 102: 993-7.

19 Penson DF, Ng C, Cai L, Rajfer J, González-Cadavid NF. Androgen and pituitary control of penile nitric oxide synthase and erectile function in the rat. Biol Reprod 1996; 55 : 567-74

20 Aversa A, Isidori AM, Spera G, Lenzi A, Fabbri A. Androgens improve cavernous vasodilatation and response to sildenafil in patients with erectile dysfunction. Clin Endocrinol (Oxf) 2003; 58: 632-8

21 Shabsigh R, Kaufman JM, Steidle C, Padma-Nathan H. Randomized study of testosterone gel as adjunctive therapy to sildenafil in hypogonadal men with erectile dysfunction who do not respond to sildenafil alone. J Urol 2004; 172: 658-63.

22 Greenstein A, Mabjeesh NJ, Sofer M, Kaver I, Matzkin H et al. Does sildenafil combined with testosterone gel improve erectile dysfunction in hypogonadal men in whom testosterone supplement therapy alone failed? Urology 2005; 173: 530-2.

23 Rosenthal BD, May NR, Metro MJ, Harkaway RC, Ginsberg PC. Adjunctive use of AndroGel (testosterone gel) with sildenafil to treat erectile dysfunction in men with acquired androgen deficiency syndrome after failure using sildenafil alone. Urology 2006; 67: 571-4.

24 Yassin AA, Saad F, Diede HE. Testosterone and erectile function in hypogonadal men unresponsive to tadalafil: results from an open-label uncontrolled study. Andrologia 2006; 38: 61-8.

25 Rosen R, Altwein J, Boyle P, Kirby RS, Lukacs B et al. Lower urinary tract symptoms and male sexual dysfunction: the Multinational Survey of the Aging Male (MSAM-7). Eur Urol 2003; 44: 637-49.

26 Taylor JM, DeSouza R, Wang R. Common approach to managing lower urinary tract symptoms and erectile dysfunction. Asian J Androl 2008; 10: 45-53.

27 Palea S \&Barras M. Comparison of the relaxant effects of alfuzosin, phentolamine and sildenafil on rabbit isolated corpus cavernosum. BJU Int 2003; 91: 873-87.

$28 \mathrm{Kim}$ NN, Goldstein I, Moreland RB, Traish AM. Alpha-adrenergic receptor blockade by phentolamine increases the efficacy of vasodilators in penile corpus cavernosum. Int Impot Res 2000; 2(Suppl 1): S26-36.

29 Oger S, Behr-Roussel D, Gorny D, Lecoz O, Lebret T et al. Combination of doxazosin and sildenafil exerts an additive relaxing effect compared with each compound alone on human cavernosal and prostatic tissue. J Sex Med 2009; 6: 836-47.

30 de Rose AF, Giglio M, Traverso P, Lantieri P, Carmignani G. Combined oral therapy with sildenafil and doxazosin for the treatment of non-organic erectile dysfunction refractory to sildenafil monotherapy. Int J Impot Res 2002; 14: 50-3.

31 Kaplan SA, Gonzalez RR, Te AE. Combination of alfuzosin and sildenafil is superior to monotherapy in treating lower urinary tract symptoms and erectile dysfunction. Eur Urol 2007; 51: 1717-23.

32 Mulhall JP, Jahoda A, Aviv N, Valenzuela R, Parker M. The impact of sildenafil citrate on sexual satisfaction profiles in men with a penile prosthesis in situ. BJU Int 2004 93: 97-9.

33 Sairam K, Kulinskaya E, McNicholas TA, Boustead GB, Hanbury DC. Sildenafil influences lower urinary tract symptoms. BJU Int 2002; 90: 836-9. 
Combination therapy for erectile dysfunction

RR Dir et al

390

34 Liguori G, Trombetta C, de Giorgi G, Pomara G, Main G et al. Efficacy and safety of combined oral therapy with tadalafil and alfuzosin: an integrated approach to the management of patients with lower urinary tract symptoms and erectile dysfunction. Preliminary report. J Sex Med 2009; 6: 544-52.

35 Blonde L, Korenman SG, Siegal RL, Orazem J. Sildenafil citrate for treatment of erectile dysfunction is similarly effective in men with type 1 or type 2 diabetes mellitus. Diabetes 2000; 49 (Suppl 1): 354 (A88).

36 Koppiker N, Boolell M, Price D. Recent advances in the treatment of erectile dysfunction in patients with diabetes mellitus. Endocr Pratt 2003; 9: 52-63.

37 Gentile V, Vicini P, Prigiotti G, Koverech A, Di Silverio F. Preliminary observations on the use of propionyl-L-carnitine in combination with sildenafil in patients with erectile dysfunction and diabetes. Cur Med Res Spin 2004; 20: 1377-84.

38 Cavallini G, Modenini F, Vitali G, Koverech A. Acetyl- L-carnitine plus propionylL-carnitine improve efficacy of sildenafil in treatment of erectile dysfunction after bilateral nerve-sparing radical retropubic prostatectomy. Urology 2005; 66: 1080-5.

39 Herman HC, Levine LA, Macaluso J Jr, Walsh M, Bradbury D et al. Can atorvastatin improve the response to sildenafil in men with erectile dysfunction not initially responsive to sildenafil? Hypothesis and pilot trial results. J Sex Med 2006; 3: 303-8.

40 Shadiack AM, Herbert GW, Silvester KR, Padron JM. Elucidating the mechanism of the erectogenic effects of PT-141, a synthetic melanocortin agonist. Society for Neuroscience: New Orleans, LA, 2003. Abstract Book: Program No. 399.4.

41 Diamond LE, Earle DC, Garcia WD, Span C. Co-administration of low doses of intranasal PT-141, a melanocortin receptor agonist, and sildenafil to men with erectile dysfunction results in an enhanced erectile response. Urology 2005; 65: 755-9.

42 Taneja R. A rational combination pharmacotherapy in men with erectile dysfunction who initially failed to oral sildenafil citrate alone: a pilot study. J Sex Med 2007; 4: 1136-41.

43 Ozdal OL, Ozden C, Gokkaya S, Urgancioglu G, Aktas BK et al. The effect of sildenafil citrate and pentoxifylline combined treatment in the management of erectile dysfunction. Int Ural Nephrol 2008; 40: 133-6.

44 Kondoh N, Higuchi Y, Maruyama T, Nojima M, Yamamoto S et al. Salvage therapy trial for erectile dysfunction using phosphodiesterase type 5 inhibitors and vitamin E: preliminary report. Aging Male 2008; 11: 167-70.
45 Lebret T, Hervé JM, Gorny P, Worcel M, Botto H. Efficacy and safety of a novel combination of I-arginine glutamate and yohimbine hydrochloride: a new oral therapy for erectile dysfunction. Eur Ural 2002; 41: 608-13.

46 Wen HS, Hsieh CH, Usu GL, Mao YC, Ling PY et al. The synergism of penile venous surgery and oral sildenafil in treating patients with erectile dysfunction. Int J Androl 2005; 28: 297-303.

47 Perimenis P, Konstantinopoulos A, Karkoulias K, Markou S, Perimeni P et al. Sildenafil combined with continuous positive airway pressure for treatment of erectile dysfunction in men with obstructive sleep apnea. Int Ural Nephrol 2007; 39: 547-52.

48 Banner LL, Anderson RU. Integrated sildenafil and cognitive-behavior sex therapy for psychogenic erectile dysfunction: a pilot study. J Sex Med 2007; 4: 1117-25.

49 Rubin S, Heiman JR, Berger RE, Murallo AV, Yung-Wen L. Comparing Sildenafil alone vs. Sildenafil plus brief couple sex therapy on erectile dysfunction and couples' sexual and marital quality of life: a pilot study. J Sex Marital The 2009; 35: 122-43.

50 John H, Lehmann K, Kauri D. Intraurethral prostaglandin improves quality of vacuum erection therapy. Eur Urol 1996; 29: 224-6.

51 Marmar JL, DeBenedictis TJ, Praiss DE. The use of a vacuum constrictor device to augment a partial erection following an intracavernous injection. J Urol 1988; 140: 975-9.

52 Chen J, Godschalk MF, Katz PG, Mulligan T. Combining intracavernous injection and external vacuum as treatment for erectile dysfunction. J Urol 1995; 153: 1476-7.

53 Carson CC, Mulcahy JJ, Govier FE. Efficacy, safety and patient satisfaction outcomes of the AMS $700 C X$ inflatable penile prosthesis: results of a long-term multicenter study. AMS 700CX Study Group. J Ural 2000; 164: 376-80.

54 Benevides MD, Carson CC. Intraurethral application of alprostadil in patients with failed inflatable prosthesis. J Urol 2000; 163: 785-76.

55 Chew KK, Stuckey BG. Use of transurethral alprostadil (MUSE) for glans tumescence in a patient with a penile prosthesis. Int J Import Res 2000; 12: 195-6.

56 Mulhall JP, Jahoda A, Avis N, Valenzuela R, Parker M. The impact of sildenafil citrate on sexual satisfaction profiles in men with a penile prosthesis in situ. BJU Int 2004; 93: 97-9.

57 Mireku-Boateng AO, Dennery M, Littlejohn J. Use of sildenafil in penile implant patients. Ural Int 2001; 66: 149-51.

58 Soderdahl DW, Petroski RA, Mode D, Schwartz BF, Thrasher JB. The use of an external vacuum device to augment a penile prosthesis. Tech Urol 1997; 3: 100-2.

Asian Journal of Andrology 